percentage increase in research budget accrues to the Commissariat à l'Energie Atomique (CEA) (18 per cent) while the highest goes to the Commissariat à l'Energie Solaire (COMES) (50 per cent). Nevertheless, CEA has a budget of 5,200 million francs ( $£ 520$ million) and COMES only $\mathbf{3 0 0}$ million francs.

Some of these increases must, however, be qualified by a French budgetary distinction between "crédits de paiement" (money actually received in 1982) and "crédits d'autorisation" (money which can be committed, as in ordering a piece of equipment, but not necessarily spent).

It is in terms of these crédits d'autorisation that there will be an increase of 29 per cent (to 25,000 million francs from 19,000 million francs). In crédits de paiement, the increase is only 15 per cent. Thus in his budget Chevènement is gambling heavily - as is all of France - on future economic success. Of what he offers to research, about half is not yet in the government's coffers. Robert Walgate

\section{UK research funding}

\section{Cutting problems}

The British Science and Engineering Research Council is alarmed that the quality of research in some outstanding science departments is being jeopardized by the reluctance of universities to be sufficiently selective in deciding where to make economies. The council's anxiety has apparently increased since the University Grants Committee informed individual universities last July of the cut in their incomes and student numbers over the next three years. Although guidance on student quotas for different subject areas was fairly specific, the council considers that advice on where to save money was too vague. It is disturbed by evidence that universities are tending to make unselective cuts.

The worry is that universities are endangering the concept of a well-found laboratory on which the dual support system for funding university research depends. The system demands that universities provide well-equipped laboratories run by tenured staff while the research councils award grants to individuals for specific research projects. The Science and Engineering Research Council intends to continue awarding grants on the merit of proposals provided that they come from laboratories with an adequate research base. But it says that if universities make cuts across the board, facilities in many departments may be so weakened that it would be unable to support their work.

That apparently has already happened on occasion in recent years. In such cases, the council has made grants conditional on the university providing the funds for basic equipment. By March 1980, the position was such that the Advisory Board for the Research Councils set up a committee to recommend what should be done. The committee has now resumed its investigations after postponing its report when the latest cuts to the universities became known.

Sir Alec Merrison, chairman of the committee, believes that it should report by the end of the year so as to provide universities with guidance on how to reorganize while minimizing the damage to research.

Judy Redfearn

\section{US engineering graduates Firms step in}

\section{Washington}

Increasingly concerned at growing bottlenecks in the production of engineers by US universities and colleges, as well as the decreasing willingness of the federal government to provide financial assistance to overcome this problem, private companies are taking matters into their own hands.

Two weeks ago, member companies of the American Electronics Association, computer and data processing equipment manufacturers who have been among the hardest hit by current shortages in qualified manpower, agreed that over the next five years they would set aside two per cent of their research and development budget to assist university and college computer science and engineering departments.

This decision could produce an extra $\$ 50$ million to help support engineering education, and follows the announcement in September that the Exxon Education Foundation is to launch a five-year, $\$ 15$-million programme of assistance to engineering schools and faculty members across the country. The money will be shared among 66 colleges, including both private and state universities. Under the programme, 100 doctoral candidates will receive an average of $\$ 50,000$ over the three years of their studies. An additional $\$ 20,000$ will be provided to 100 departments of engineering, earth sciences and computer science specifically to help subsidize higher salaries for young teaching faculty members .

Although the Exxon Foundation's grant programme is said to be the largest ever undertaken by a corporate entity, it is not unique. IBM, for example, has awarded 278 graduate and predoctoral fellowships in mathematics, science and engineering in the past three years, and is making 180 grants of $\$ 25,000$ each to university departments between 1980 and 1984 - a total of $\$ 4.5$ million.

Furthermore, the private sector is so concerned that efforts to revitalize the US technological base could founder on a shortage of adequately trained engineers that Exxon and IBM have joined with six other major corporations (AT\&T, du Pont, General Electric, General Motors, General Telephone and Electronics and Union Carbide) to sponsor a two-year programme in Washington under the umbrella of the American Society for Engineering Education to consider how the federal government might help to solve the shortage of engineering college faculty.

Although pay differentials are the most widely-quoted cause for the current shortage, other factors from federal regulation of research to the obsolesence of teaching equipment - have contributed to the crisis.

There is no shortage of potential students. News of the heavy demands for engineering graduates, often being offered starting salaries of $\$ 25,000$ a year or more, has filtered quickly down into the schools, and some universities and colleges say that they are now having to limit the intake of engineering undergraduates.

According to figures being prepared by the National Science Foundation, however, private industry employers are now having "major difficulties" in filling their requirements for computer, electrical/electronic and chemical engineers. Employers had reported "some difficulties" in recruiting mechanical, industrial, petroleum and mining engineers, but said that demand and supply were in balance for aerospace engineers, while there was evidence of an oversupply of civil engineers.

Nor is it only the private sector that is worried. General Robert T. Marsh, commander of the US Air Force Systems Command is concerned that a shortage of highly qualified scientists and engineers is threatening the US defence capability.

The Reagan Administration has already advertised its concern for the general shortage of engineering graduates in both the private and military sectors. It insists that this problem should, where possible, be solved through the maximum involvement of private companies.

Some of these efforts, however, may already be beginning to backfire. Dr Ivan Bennett, dean of New York University Medical Center, has told the advisory committee to the director of the National Institutes of Health that although recent changes in the tax law make it more attractive for companies to donate secondhand research equipment to universities, some corporate leaders had told him that the value of this incentive was virtually cancelled out by the accelerated depreciation now allowed on such equipment. David Dickson

\section{Genetic engineering Biogen digs in}

\section{Zurich}

Within a period of days Biogen, one of the first biotechnology companies, has opened an American counterpart to its Geneva laboratory, appointed one of last year's Nobel prizewinners as chairman of its board of directors and secured $\$ 20$ million of additional financial backing. Biogen seems bent on being among the ten 
per cent of biotechnology companies that survive the next five years.

The new chairman of the Biogen board, Professor Walter Gilbert, has been closely associated with the company since its inception in 1978 both as chairman of the board of scientific directors, a role in which he will continue, and as co-chairman of the board of directors (since mid-1979). He moves to the position of chairman with the departure of the other co-chairman, $\mathrm{Dr}$ Robin Nicholson of Inco, to the British Cabinet Office (see p.596). Since the job of chairman is full-time, Professor Gilbert is taking a year's leave of absence from Harvard. And since he hopes to remain as chairman, he is discussing with Harvard University ways and means by which he can permanently keep both his laboratory at Harvard and his position with Biogen.

The American laboratory of Biogen Inc. opens this week on a site two blocks away from the Massachusetts Institute of Technology in Cambridge. It should be staffed with about 35 scientists by the end of the year and may well have a director within weeks. The Cambridge laboratory is destined to concentrate on the more chemical and processing sides of biotechnology, with a particular interest in bacterial methods of producing ethanol and chemical feedstocks. Meanwhile the Geneva laboratory of Biogen SA (the offspring together with Biogen Inc. of Biogen NZ, registered in Curaçao) will continue to concentrate on pharmaceuticals. The Geneva laboratory is itself due to grow rapidly, moving into new premises and doubling in size this year.

All this expansion, for a company that has not yet a single product on sale, needs just the kind of financial backing represented by the $\$ 20$ million deal closed this week with private European financial institutions (insurance companies and banks mainly in the United Kingdom). But when can the backers, which include Inco, General Metropolitan, Schering-Plough and Monsanto, expect to see some return? Professor Gilbert anticipates that Biogen's first sales should be within two years. Bacterially produced human leukocyte interferon is already in the first phase of clinical trial in the Netherlands and both a foot and mouth disease vaccine and a hepatitis $B$ vaccine are being tested in animals. The interferon is being produced in Zurich for Schering-Plough; and Biogen has very recently concluded negotiations with the Japanese pharmaceutical company, Green Cross, for the eventual marketing of a hepatitis $B$ vaccine.

At present Biogen relies on connections with established companies for the marketing side of its business but it plans to become in time (and in the jargon) vertically-integrated. No doubt it also plans to go public in due course but, despite speculation earlier this year, Professor Gilbert will say only that Biogen is a private company and plans to remain so for some time.

Peter Newmark

Biotechnology

\section{UN plans centre}

New York

An International Centre for Genetic Engineering is being planned at the United Nations. Proposed last year by UN officials, the centre would attempt to promote technology transfer between developed and developing nations in a noncommercial setting.

At a meeting in Vienna last February under the auspices of the United Nations Industrial Development Organization (UNIDO), scientists and officials from developing countries worked out a plan for a facility to extend the industrial application of genetic engineering to developing countries. The working model appears to be the International Centre for Theoretical Physics in Trieste. The centre would entertain scientists from both developed and

\section{Aid without reactors}

The United Kingdom Atomic Energy Authority confirmed last week that its Harwell laboratory is acting as a consultant to the King Abdulaziz University in Jeddah, Saudi Arabia, on the development of an international energy research centre. But the authority insists that no part of its brief will be concerned with the provision of nuclear reactors, even for research. Rather, the Harwell laboratory will be giving advice only on the establishment of a laboratory of materials science.

By all accounts (of which there are few), the Jeddah centre is to be a fully fledged research laboratory concerned with all non-fossil sources of energy. One of the objectives is to create a laboratory at which scientists and engineers from outside Saudi Arabia will work alongside local people, thus helping with training, also known as technology transfer. Much of the research programme will be concerned with solar energy with which Saudi Arabia is almost as well endowed as with petroleum.

The importance of a materials science laboratory at the centre stems not merely from the possible use of semiconductor devices for the direct conversion of solar energy into electricity but also from the applications of ceramic and other materials in the fabrication of other solar energy devices, from mirrors to windmills.

The Harwell laboratory is thought to be only one of several consultants; the identities of the others are not known. Its brief appears to involve the specification of laboratory facilities and equipment and the provision of advice on the scale on which research should be carried out. developing nations in order to deal with scientific problems unique to the poorer countries.

The centre would serve as an information network and as a training ground for scientists from developing countries, and might include on-site laboratories for research and development. Suggested projects already include work on vaccines for malaria and other diseases, the transfer of nitrogen-fixation genes to plants and the development of plants resistant to drought and herbicides. Agricultural specialists consulted by the United Nations foresee the creation of high technology plants capable of yielding well even with the relatively less advanced agricultural technology of the poorer nations.

There is, as yet, no indication of where the centre would be located but several countries, including Mexico and Argentina, have expressed an interest. The host country would be expected to put up money to help finance the enterprise. Other financial support would come from UNIDO funds, and UN officials say they are trying to interest several OPEC nations.

UNIDO representatives say the proposal has been well received wherever they have travelled in South America, Asia and the Middle East. But apart from the political problem of where to place such a centre, scientists researching the plan have said that some developed nations represented in the United States by the Department of Commerce and the State Department - have been hesitant to commit themselves wholeheartedly to such a broad transfer of technology.

In addition, some Third World research directors have suggested that they would prefer that the United Nations should invest in factories rather than in building a research centre. They argue that many nations which need the fruits of recombinant DNA technology lack a nucleus of native scientists capable of taking advantage of such a facility.

The next UNIDO meeting takes place in Vienna this month, and the United States, Japan, Pakistan, India, The Netherlands, West Germany and the United Kingdom have so far agreed to attend. Final decisions about the size and location of the proposed centre are expected by January 1982.

Michael D. Stein

\section{Research in Norway Oiling the wheels}

\section{Bergen}

A Norwegian government commission says that spending on the country's industrial science and technology research is grossly inadequate and that a doubling of expenditure in the next few years is needed. It is hoped that industry itself would provide most of the money, although the commission, chaired by banker Lars Uno Thulin, urges the public sector to take an initiative by spending an extra $£ 25$ million 